\title{
The activity of pathogenesis related proteins in smut resistant and susceptible sugarcane (GT54-9) mutants induced by gamma radiation
}

\begin{abstract}
The activity of six pathogenesis related (PR) proteins (polyphenole oxides, phenylalanine ammonia lyase, peroxidase, esterase, chitinase and $\beta 1,3$ glucanase) in sugarcane were used to detect the variation between smut susceptible and resistant sugarcane clones generated from the moderately resistant sugarcane cultivar GT 54-9 using gamma radiation. Activity of PR proteins was monitored in healthy and artificially infected plants. A dramatic increase in the tested enzymes (phenylalanine ammonia lyase, peroxidase, esterase and chitinase) was noticed in the resistant infected (RI) plants compared to the susceptible infected (SI) plants and to the control. Generally, the levels of the tested enzymes in the (SNI) plants were lower than those recorded in the (RNI) or the moderately resistant (GT 54-9 cultivar) control plants.
\end{abstract}

Keywords: sugarcane smut, ustilago scitaminea, pathogenesis related proteins, polyphenole oxidase, phenylalanine ammonia lyase, peroxidase, esterase, chitinase, $\beta 1,3$ glucanase
Volume I Issue 4 - 2014

Esh AMH, ' Guirgis AA, ${ }^{2}$ El-kholi MMA, ${ }^{2}$ ElAbsawy $\mathrm{EA},{ }^{2}$ Nasr $\mathrm{MI},{ }^{2}$ Hassanien $\mathrm{EH}^{3}$

'Sugar Crops Research Institute, Cairo University, Egypt

${ }^{2}$ Genetic Engineering and Biotechnology Research Institute,

Minufiya University, Egypt

${ }^{3}$ Faculty of Agriculture,Ain Shams University, Egypt

Correspondence: Esh AMH, Sugar Crops Research Institute, Cairo University, Agricultural Research Center, 9 Cairo University street, Giza sugar crops research institute, Tel +201005506639, Email aymanesh@gmail.com

Received: August 25, 2014 | Published: October 13, 2014
Abbreviations: PR, pathogenesis related proteins; PPO, polyphenol oxidase; PAL, phenylalanine ammonia lyase; EST, esterases; POX, peroxidase; IDOC, \% of increase/decrease over control; RI, resistant infected; SI, susceptible infected; Syd, sporisorium scitamineum; RNI, resistant non-infected

\section{Introduction}

Smut is an important economic disease of sugarcane. The causal organism, Ustilago scitaminea Syd.; (Sporisorium scitamineum (Syd.) M. Piepenbr., M. toll \& Oberw.) was first reported in Natal in 1877 in South Africa and now smut occurs in most of the sugarcane producing areas of the world. ${ }^{1}$ The disease aggressively affects plant growth and cane yield. ${ }^{2}$

Plants producing a number of compounds and proteins in response to pathogen infection. These compounds and proteins are believed to have a high importance in protecting them from the deleterious effects of the pathogen. These include the accumulation of antimicrobial compounds $^{3-5}$ and the physical strengthening of plant cell walls through increased production of hydroxyproline-rich glycoproteins, lignin and suberin. ${ }^{6-8}$ The produced proteins (pathogenesis-related (PR) proteins) are known to be highly resistant to proteolytic degradation. ${ }^{9}$ The PR proteins have been classified into 14 families based on the amino acid sequences, serological relationship and/or enzymatic or biological activity. ${ }^{10}$ Many PR proteins exhibit direct antifungal activity against a wide range of fungal pathogens. ${ }^{11}$

Resistance to smut has been associated with the accumulation of free or conjugated polyamines in sugarcane tissues. ${ }^{12,13}$ Several glycoproteins produced in sugarcane tissues during the infection process $^{2}$ found affecting the fungal spore germination negatively. ${ }^{14-16}$ Some of glycoproteins have the ability to affect the cytoplasmic polarity during spore germination ${ }^{14}$ and impede cell polarization by inhibiting the protrusion of the germ tube and spore germination. The inhibition of teliospore germination constitutes a defense mechanism involved in the resistance of sugarcane to smut. ${ }^{15,16}$
The aim of this study was to investigate the PR proteins changes in young sugarcane plants and to relate susceptibility or resistance to smut with changes in the levels of PR proteins produced by inoculated smut sporidia.

\section{Materials and methods}

\section{Plant materials}

Ten smut resistant sugarcane clones were obtained from (Sugar Crops Research Institute, Giza, Egypt) (GT 54-9, C9/0.5Kr-11, $\mathrm{C} 9 / 0.5 \mathrm{Kr}-32, \mathrm{C} 9 / 0.5 \mathrm{Kr}-42, \mathrm{C} 9 / 0.5 \mathrm{Kr}-46, \mathrm{C} 9 / 1 \mathrm{Kr}-3, \mathrm{C} 9 / 2 \mathrm{Kr}-1$, $\mathrm{C} 9 / 3 \mathrm{Kr}-63, \mathrm{C} 9 / 3 \mathrm{Kr}-69$ and $\mathrm{C} 9 / 3 \mathrm{Kr}-8)$ and 10 susceptible clones $(\mathrm{C} 9 / 2 \mathrm{Kr}-19, \mathrm{C} 9 / 2 \mathrm{Kr}-4, \mathrm{C} 9 / 3 \mathrm{Kr}-38, \mathrm{C} 9 / 3 \mathrm{Kr}-45, \mathrm{C} 9 / 3 \mathrm{Kr}-47$, $\mathrm{C} 9 / 3 \mathrm{Kr}-52, \mathrm{C} 9 / 3 \mathrm{Kr}-56, \mathrm{C} 9 / 3 \mathrm{Kr}-70, \mathrm{C} 9 / 1 \mathrm{Kr}-3$ and $\mathrm{C} 9 / 3 \mathrm{Kr}-79)$. All clones were selected from a former mutation induced clones by gamma radiation to the moderately resistant sugarcane cultivar GT 54-9.

Sugarcane stalks of each mutant were stripped of all leaves, cut into one bud setts, then given a hot water treatment for $10 \mathrm{~min}$ at $52^{\circ} \mathrm{C}$ to stimulate growth. The setts were dipped into $30 \mathrm{mg}$ a.i./L fungicide solution (Benomyl). The setts were cultivated ( $3 \mathrm{~cm}$ depth) in $25 \mathrm{~cm}$ diameter pots filled with sand, pitmos and soil $(1: 1: 1)$ each pot contained 3setts. The greenhouse temperature was $28^{\circ} \mathrm{C} \pm 2 .{ }^{17}$

After the germinating shoots reach $20 \mathrm{~cm}$ long (45days old), pots of each mutant divided to two groups over three replicates (3pots each) the plants of the first group inoculated with $U$. scitaminea and the plants of the second group inoculated with sterile distilled water to serve as a control.

\section{Fungal material}

Single haploid plus $(+)$ and minus $(-)$ spores from germinated teliospores of $U$. scitaminea-isolated from commercial field located in Quena governorate, Egypt were prepared using the method described by Benhamou et al. ${ }^{18}$ Two isolates of single haploid $(+)$ and $(-)$ yeast- 
like culture of $U$. scitaminea grown on GYC medium for $72 \mathrm{~h}$. at $28^{\circ} \mathrm{C}$. After incubation the cultures centrifuged at $8000 \mathrm{rpm}$ for 5 minutes. The supernatant discarded and the collected cells washed 2 times using sterile distilled water and adjusted to reach $2 \times 105$ spores per ml using a haemocytometer. Equal volumes of haploid $(+)$ and $(-)$ yeast-like spore suspension were mixed and incubated for $3 \mathrm{~h}$. at $30^{\circ} \mathrm{C}$ before inoculation. ${ }^{18}$ To reduce surface tension, Tween 20 was added at a rate of $100 \mathrm{ul}$ per $100 \mathrm{ml}$ of spore suspension prior inoculation. ${ }^{17}$

\section{Inoculation}

The hypodermic injection technique according to ${ }^{17}$ was used to inoculate the emerged plants. Plant Shoots were inoculated when they reached $20 \mathrm{~cm}$ long using $50 \mu \mathrm{l}$ of a suspension containing $2 \times 105$ sporidia/ml of a 1:1 mixture (plus and minus) of the isolated mating cell types (inoculated plants) or with $50 \mu 1$ of sterile water (noninoculated). Inoculation was carried out in the apical portion of the stem through the leaf sheath to ensure its contact with the meristematic region of the stem, which is the specific site of mycelium penetration and development in nature, when airborne dispersed teliospores are deposited on vegetative buds. Inoculum was infected into the stem $3 \mathrm{~cm}$ above the first leaf with a visible dewlap. Smut inoculated and non-inoculated plants were sampled at $120 \mathrm{~h}$ post-inoculation. Stem segments of $6 \mathrm{~cm}$ long ( $3 \mathrm{~cm}$ above and below the point of inoculation) of the inoculated and non-inoculated plants sampled at different time intervals were ground in liquid nitrogen. Total protein in each clone was determined according to. ${ }^{19}$ Samples of $1.0 \mathrm{~g}$ of the fine powder were extracted for each enzyme system. The percentage of increase/ decrease over control (\%IDOC) of each enzyme in infected and noninfected plants was calculated using the formula: $((\mathrm{T}-\mathrm{C}) / \mathrm{C}) \times 100$ Where:

$\mathrm{C}=$ enzyme level in infected or non infected control GT 54-9 cultivar.

$\mathrm{T}=$ enzyme level in infected or non infected clones.

\section{Analysis of Polyphenol Oxidase (PPO) activity}

Sugarcane samples were extracted according to the method described by Malik et al. ${ }^{20}$ The enzyme extract was prepared by suspending $1.0 \mathrm{~g}$ sample in $0.1 \mathrm{M}$ sodium phosphate buffer $\mathrm{pH} 7$ ( $2 \mathrm{ml} / \mathrm{g}$ fresh weight), then centrifuged at $6000 \mathrm{rpm}$ for $30 \mathrm{~min}$. under $4^{\circ} \mathrm{C}$, the clear extract was collected, completed to $15 \mathrm{ml}$ volume using phosphate buffer and used as a crude enzyme source. The reaction mixture contained $0.2 \mathrm{ml}$ of crude enzyme source, $1 \mathrm{ml}$ of phosphate buffer $\mathrm{pH} 7 ; 1 \mathrm{ml}$ of $10-3 \mathrm{M}$ catechol and completed with distilled water up to $6 \mathrm{ml}$. The reaction was incubated for $30 \mathrm{~min}$. at $30^{\circ} \mathrm{C}$. One unit of PPO was expressed as the change in absorbance at $420 \mathrm{~nm}$, and expressed as unit's $\min ^{-1} \mathrm{~g}^{-1}$ fresh wt. ${ }^{21}$

\section{Analysis of Phenylalanine Ammonia Lyase (PAL) activity}

A procedure described by Zucker ${ }^{22}$ was used; one gram of sample was suspended in $5 \mathrm{ml}$ of $0.1 \mathrm{M}$ borate buffer $(\mathrm{pH} 8.8)$ and $54 \mathrm{mM}$ $\beta$-mercaptoethanol. The mix centrifuged at $10,000 \mathrm{rpm}$ at $4^{\circ} \mathrm{C}$ for 10 minutes then $1 \mathrm{ml}$ of the supernatant was mixed with $1 \mathrm{ml} 30 \mathrm{mM}$ of phenylalanine and $1 \mathrm{ml}$ borate buffer and incubated for one hour at $40^{\circ} \mathrm{C}$ for reaction termination, $0.2 \mathrm{ml}$ of $5 \mathrm{NHCl}$ was added then the volume increased up to $4 \mathrm{ml}$ using distilled water. The amount of transcinnamic acid formed in the reaction was measured at $290 \mathrm{~nm}$ and calculated according to Saunders et al., ${ }^{23}$ as the change in absorbance of 0.01 is equivalent to the production of $3.09 \mathrm{n}$ moles of cinnamic acid. The specific activity of the enzyme was expressed as moles of cinnamic acid produced per hour/gm of the tissue.

\section{Extraction procedure for peroxidases and esterases}

For estimation of peroxidases and esterases, one gram of sugarcane sample was suspended in $2 \mathrm{ml}$ of cold freshly prepared $10 \%$ polyvinylpyrrolidone in $0.5 \mathrm{M}$ tris $\mathrm{HCl}$ buffer $(\mathrm{pH} 7.2)$ and the ratio was kept 2:1 (v/w) for buffer and material. The slurry was centrifuged at $14000 \mathrm{rpm}$ for 20 minutes at $4{ }^{\circ} \mathrm{C}$, and the resulted supernatant was used for enzyme assay.

\section{Estimation of Esterases (EST)}

Oneml of crude enzyme was added to $5 \mathrm{ml}$ of the reaction mixture and kept at $37^{\circ} \mathrm{C}$ for $1 \mathrm{~h}$. The reaction mixture was prepared by dissolving $200 \mathrm{mg} \alpha$-napthyl acetate in $10 \mathrm{ml}$ of $50 \%$ acetone and $200 \mathrm{mg}$ Fast Blue RR salt in $90 \mathrm{ml}$ of $0.2 \mathrm{M}$ of phosphate buffer $(\mathrm{pH}$ 7.0). The components of the reaction mixture were mixed together and filtered through Whatman No.1 filter paper in the dark at $4^{\circ} \mathrm{C}$. The activity was measured at $600 \mathrm{~nm}$ and expressed as unit's min $^{-1} \mathrm{~g}^{-1}$ fresh wt. ${ }^{24}$

\section{Estimation of peroxidases}

The reaction mixture was prepared as previously described by Malik et al. ${ }^{20}$ The mixture contained, $0.5 \mathrm{ml}$ phosphate buffer $\mathrm{pH} 7$; $0.2 \mathrm{ml}$ enzyme source; $0.3 \mathrm{ml}$ of $0.05 \mathrm{M}$ pyrogallol; $0.1 \mathrm{ml}$ of $1 \%(\mathrm{v} / \mathrm{v})$ $\mathrm{H}_{2} \mathrm{O}_{2}$. The total mixture volume was raised to $3 \mathrm{ml}$ using distilled water. The reaction mixture was incubated at $30^{\circ} \mathrm{C}$ for $5 \mathrm{~min}$. Then the reaction stopped by adding $0.5 \mathrm{ml}$ of $5 \%(\mathrm{v} / \mathrm{v}) \mathrm{H}_{2} \mathrm{O}_{2} \cdot{ }^{21}$ One unit of peroxidase activity was expressed as the changes in absorbance at $425 \mathrm{~nm}$ and expressed as unit's min $^{-1} \mathrm{~g}^{-1}$ fresh wt.

\section{Determination of Chitinase}

One gram of sample was suspended in an extraction buffer consisting of $0.1 \mathrm{M}$ acetate buffer ( $\mathrm{pH} 5.0$ ) containing $0.1 \%(\mathrm{~W} / \mathrm{V})$ each of ascorbic acid and sodium sulphite and 5\% PVP. The homogenates were centrifuged at $12,000 \mathrm{rpm}$ at $4^{\circ} \mathrm{C}$ for $30 \mathrm{~min}$., and then the supernatant was used for enzyme assay. A mixture of crude enzyme source $(1 \mathrm{ml})$ and suspension of colloidal chitin $(1 \mathrm{ml} ; 0.1 \%$ in $50 \mathrm{mM}$ sodium acetate buffer; $\mathrm{pH} 5$ ) was incubated at $38^{\circ} \mathrm{C}$ in a water bath with constant shaking. After $2 \mathrm{hr}$, the release of $\mathrm{N}$-acetylglucosamine in the reaction mixture was estimated by the method of Reissig et al. ${ }^{25}$ The enzyme activity was determined using $\mathrm{N}$-acetylglucosamine (Sigma) as the standard. Absorbance was measured at $660 \mathrm{~nm}$. One unit of chitinase is defined as the amount of enzyme producing $1 \mu \mathrm{mol}$ $\mathrm{N}$-acetylglucosamine/min in $1 \mathrm{ml}$ of reaction mixture under standard assay conditions. Specific activity was expressed as unit's $\min ^{-1} \mathrm{~g}^{-1}$ fresh wt.

\section{Determination of $\beta-I, 3$ glucanase}

One gram of sample was suspended in an extraction buffer consisting of $0.1 \mathrm{M}$ acetate buffer ( $\mathrm{pH} 5.0$ ) containing $0.1 \%(\mathrm{~W} / \mathrm{V})$ each of ascorbic acid and sodium sulphite and 5\% PVP. The homogenates were centrifuged at $12,000 \mathrm{rpm}$ at $4^{\circ} \mathrm{C}$ for $30 \mathrm{~min}$., the supernatant was used for enzyme assay. ${ }^{26}$

Total activity of $\beta-1,3$ glucanase was determined by measuring the released reducing sugar from laminarin (Sigma-Aldrich) as a substrate. ${ }^{26}$ The assay mixture was consisted of $0.8 \mathrm{ml}$ of $0.1 \mathrm{M}$ 
acetate buffer $\mathrm{pH} 5.0$ containing $1 \%$ laminarin and $0.4 \mathrm{ml}$ of enzyme extract. After 30 minutes incubation $30^{\circ} \mathrm{C}$, the reducing substances were colorimetrically estimated according to $0^{27,28}$ at $660 \mathrm{~nm}$. The standard curve of glucose was used as reference. Specific activity was expressed as unit's $\min ^{-1} \mathrm{~g}^{-1}$ fresh wt.

All the chemicals and reagents used in this work were produced by Sigma Aldrich and Amresco. The colorimetric assays were carried out using Spectronic 601; Milton Roy, Rochester, NY spectrophotometer. Data of the present work were statistically analyzed by analysis of variance using a complete randomize design with 3 replicates according to ${ }^{29}$ using SPSS system version $8^{30}$

\section{Results and discussion}

The germination of Ustilago scitaminea spores occurs on the internode surface and it is followed by appressoria formation, mainly on the inner scale of young buds and on the bases of emerging leaves. ${ }^{31}$ The entry of the germ tube into the bud meristem occurs between 6 and 36h., after the teliospores are deposited on the surface. ${ }^{32}$ After the infection, the fungal hyphae grow throughout the infected plant, but mostly in the parenchyma cells of the lower internodes. In the upper internodes, hyphal growth concludes with the formation of the whip (sori with teliospores). It has been proposed that varied resistance of sugarcane is determined by several morphological features of buds. ${ }^{31}$ In this work we used injection as an inoculation method to determine the physiological resistance.

\section{Polyphenoloxidase (PPO) activity}

The levels of polyphenoloxidase in the resistant infected (RI) and non-infected (RNI) sugarcane clones (Table 1) were significantly higher than in the susceptible infected (SI) and non-infected (SNI) sugarcane clones. In susceptible clones, it was noticed that the levels of PPO were lower than in the control (GT 54-9 cultivar) in both infected and non-infected treatments while in resistant varieties the levels of PPO were higher in non-infected treatment except the clones $\mathrm{C} 9 / 3 \mathrm{Kr}-63$ and $\mathrm{C} 9 / 3 \mathrm{Kr}-8$ and the clones $\mathrm{C} 9 / 0.5 \mathrm{Kr}-46, \mathrm{C} 9 / 1 \mathrm{Kr}-3$, $\mathrm{C} 9 / 3 \mathrm{Kr}-63, \mathrm{C} 9 / 3 \mathrm{Kr}-69$ and $\mathrm{C} 9 / 3 \mathrm{Kr}-8$ in infected treatment. In susceptible clones, the percentage of PPO level reduction compared to that in control (\% IDOC) ranged from 9.61 to $41.98 \%$ in non infected plants and from $37.99 \%$ to $52.31 \%$, while in resistant clones the increase of PPO level in non-infected clones ranged from $0.27 \%$ and $26.74 \%$ and the reduction was less than $3 \%$ in two clones and in infected clones the increase ranged from 2.63 to $5.51 \%$ and the reduction ranged from 0.56 to $8.1 \%$ (Figure 1 ).

Table I Specific activity of poly phenol oxidase (PPO) in healthy and U. scitaminea infected sugarcane resistant and susceptible mutants

\begin{tabular}{|c|c|c|c|c|c|c|}
\hline \multirow{2}{*}{ Resistance } & \multirow{2}{*}{ Clone } & \multicolumn{4}{|c|}{ Polyphenoloxidase (Units $\mathrm{min}^{-1} \mathrm{~g}^{-1}$ fresh wt.) } & \multirow{2}{*}{ Mean } \\
\hline & & Non-Infected & \% IDOC* & Infected & \% IDOC* & \\
\hline \multirow{10}{*}{ Susceptible } & C9/2Kr- 19 & $22.48 \mathrm{Imn}$ & $\downarrow 33.38$ & $25.48 \mathrm{~lm}$ & $\downarrow 48.86$ & \multirow{10}{*}{24.423 I B } \\
\hline & $\mathrm{C} 9 / 2 \mathrm{Kr}-4$ & $19.58 n$ & $\downarrow 41.98$ & 25.851 & $\downarrow 48.12$ & \\
\hline & C9/3Kr-38 & $20.90 \mathrm{mn}$ & $\downarrow 38.09$ & $25.28 \mathrm{~lm}$ & $\downarrow 49.26$ & \\
\hline & $\mathrm{C} 9 / 3 \mathrm{Kr}-45$ & $20.93 \mathrm{mn}$ & $\downarrow 37.98$ & $24.68 \mathrm{~lm}$ & $\downarrow 50.46$ & \\
\hline & C9/3Kr-47 & $22.87 / \mathrm{mn}$ & $\downarrow 32.25$ & $26.78 \mathrm{kl}$ & $\downarrow 46.23$ & \\
\hline & C9/3Kr-52 & $22.3 \mathrm{IImn}$ & $\downarrow 33.91$ & $24.26 \mathrm{lmn}$ & $\downarrow 51.31$ & \\
\hline & C9/3Kr-56 & $23.781 \mathrm{mn}$ & $\downarrow 29.55$ & $26.98 \mathrm{kl}$ & $\downarrow 45.85$ & \\
\hline & C9/3Kr-70 & $23.501 \mathrm{mn}$ & $\downarrow 30.38$ & $23.761 \mathrm{mn}$ & $\downarrow 52.31$ & \\
\hline & C9/IKr-I3 & $22.341 \mathrm{mn}$ & $\downarrow 33.82$ & $25.24 \mathrm{ijk}$ & $\downarrow 49.34$ & \\
\hline & C9/3Kr-79 & $30.5 \mathrm{ljk}$ & $\downarrow 9.61$ & $30.89 \mathrm{ijk}$ & $\downarrow 37.99$ & \\
\hline \multirow{12}{*}{ Resistant } & Mean & 22.9234 & & 25.9228 & & \multirow{12}{*}{ 43.9238 A } \\
\hline & C9 Cont. & $33.76 \mathrm{ij}$ & & 49.83abcd & & \\
\hline & C9/0.5Kr-I I & $42.55 \mathrm{fgh}$ & $\uparrow 26.06$ & $51.78 \mathrm{abc}$ & $\uparrow 3.91$ & \\
\hline & C9/0.5Kr-32 & $40.97 \mathrm{~h}$ & $\uparrow 21.36$ & $53.85 a$ & $\uparrow 8.06$ & \\
\hline & $\mathrm{C} 9 / 0.5 \mathrm{Kr}-42$ & 42.79fgh & $\uparrow 26.74$ & $51.14 a b c$ & $\uparrow 2.63$ & \\
\hline & $\mathrm{C} 9 / 0.5 \mathrm{Kr}-46$ & 4I.I7gh & $\uparrow 21.96$ & $48.95 \mathrm{bcd}$ & $\downarrow 1.76$ & \\
\hline & C9/IKr-3 & $33.85 \mathrm{ij}$ & $\uparrow 0.27$ & $47.50 \mathrm{cde}$ & $\downarrow 4.67$ & \\
\hline & $\mathrm{C} 9 / 2 \mathrm{Kr}-\mathrm{I}$ & 44.14efgh & $\uparrow 30.74$ & $52.58 \mathrm{ab}$ & $\uparrow 5.5 \mathrm{I}$ & \\
\hline & $C 9 / 3 \mathrm{Kr}-63$ & $32.88 \mathrm{ij}$ & $\downarrow 2.59$ & $47.09 \mathrm{cdef}$ & $\downarrow 5.49$ & \\
\hline & C9/3Kr-69 & $35.43 i$ & $\uparrow 4.94$ & 45.79defg & $\downarrow 8.10$ & \\
\hline & C9/3Kr-8 & $32.83 \mathrm{ij}$ & $\downarrow 2.74$ & 49.55abcd & $\downarrow 0.56$ & \\
\hline & Mean & 38.0400 & & 49.8075 & & \\
\hline \multicolumn{2}{|l|}{ Mean } & 34.263 I B & & $43.1359 \mathrm{~A}$ & & \\
\hline \multicolumn{7}{|c|}{ LSD at $(0.05)$ for: } \\
\hline \multicolumn{2}{|c|}{ Resistance (R): } & \multicolumn{4}{|l|}{6.361} & \\
\hline \multicolumn{2}{|l|}{ Infection (I): } & \multicolumn{4}{|l|}{5.724} & \\
\hline \multicolumn{2}{|l|}{ Clones (C): } & \multicolumn{4}{|l|}{5.724} & \\
\hline \multicolumn{2}{|l|}{ RxIxC: } & \multicolumn{4}{|l|}{4.217} & \\
\hline
\end{tabular}

*IDOC, \% of Increase/Decrease over control; up arrows ( $\uparrow$ ), increase; down arrow ( $\downarrow$ ), decrease

*Different letters in means indicate a significant difference PPO, polyphenoloxidase 
Many workers have reported the increase in the activity of polyphenole oxidase in resistant varieties. Polyphenol enzymes (catecholase and cresolase) have been reported to be responsible for in vivo synthesis and accumulation of phenolic compounds. ${ }^{33,34}$

The importance of polyphenoloxidase activity in disease resistance is due to its property to oxidize phenolic compounds to quinines which are often more toxic to microorganisms than the original phenols. It is reasonable to assume that an increased activity of polyphenoloxidase results in higher concentration of toxic products of oxidation and therefore causes greater degree of resistance to infection. ${ }^{35}$ Sundar et al., ${ }^{36}$ reported that polyphenoloxidase activity is related to resistance against red rot disease in sugarcane.

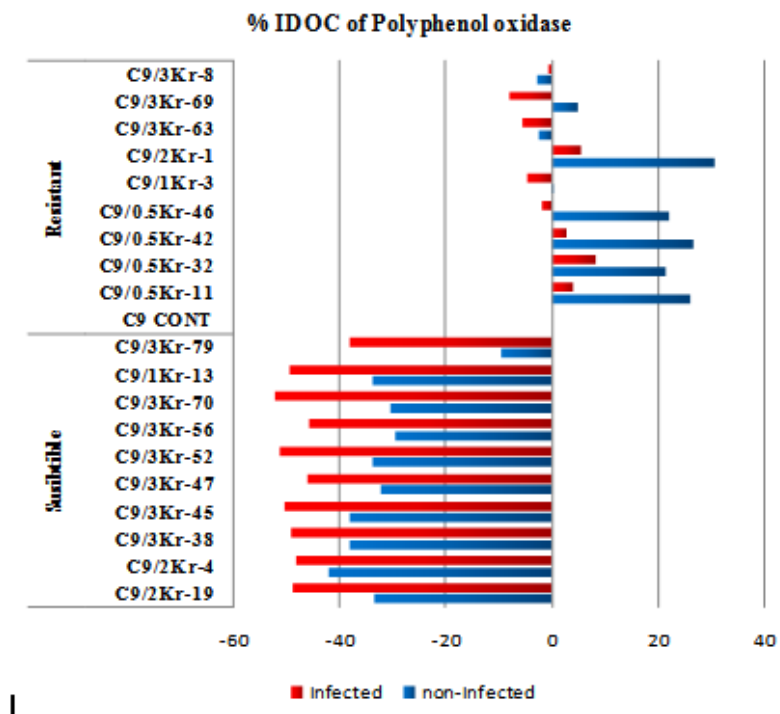

Figure I Percentage of Increase/Decrease over control (\%IDOC) of polyphenoloxidase (PAL) in healthy and $U$. scitaminea infected sugarcane resistant and susceptible GT54-9 mutants.

\section{Phenylalanine Ammonia lyase (PAL) activity}

The results demonstrated that the specific activity of Phenylalanine ammonia lyase showed a similar pattern of increase as for the activity of PPO in selected resistant and susceptible clones of sugarcane. In the present study, it was noticed that the PAL activity was significantly higher in infected and non infected resistant clones compared to the susceptible ones (Table 2).

In susceptible clones the percentage of PAL level reduction than in control GT 54-9 cultivar. The \% IDOC decreased in susceptible clones and ranged from 37.66 to $55.84 \%$ in non-infected plants and from 2.48 to $18.73 \%$ in infected plants except for four clones $(\mathrm{C} 9 / 3 \mathrm{Kr}-45, \mathrm{C} 9 / 3 \mathrm{Kr}-47, \mathrm{C} 9 / 3 \mathrm{Kr}-52$ and $\mathrm{C} 9 / 3 \mathrm{Kr}-56)$ the PAL activity increased by $(11.11,27.69,16.08$ and $0.16 \%$ respectively) compared to the control. On the other hand, in resistant non-infected clones the \% IDOC decreased compared to the control. The reduction of PAL activity ranged from 8.22 and $22.07 \%$. In resistant noninfected clones PAL activity significantly increased to the maximum $32.0 \%$ and a minimum of $22.55 \%$ (Figure 2 ).

Phenylalanine ammonia lyase activity is fundamental to maintain or increase the synthesis of all these phenolics and according to De Armas et al. ${ }^{37}$ resistance to smut in sugarcane is associated with the possibility of maintaining high levels of PAL activity. Singh et al., ${ }^{38}$ reported higher activity of PAL in red rot resistant cultivars of sugarcane than the susceptible ones. On the other hand, ${ }^{39-41}$ reported that the increase of PAL is associated with the increase in lignin synthisis in disease resistant plants.

Crude elicitor prepared from S. scitamineum mycelium induces high phenylalanine ammonia-lyase activity without accumulation of free hydroxyl cinnamic acids and moderately high peroxidases activity, mainly in resistant cultivars. ${ }^{37}$

\section{\% IDOC of Phenyla lanine ammonia layase (PAL)}

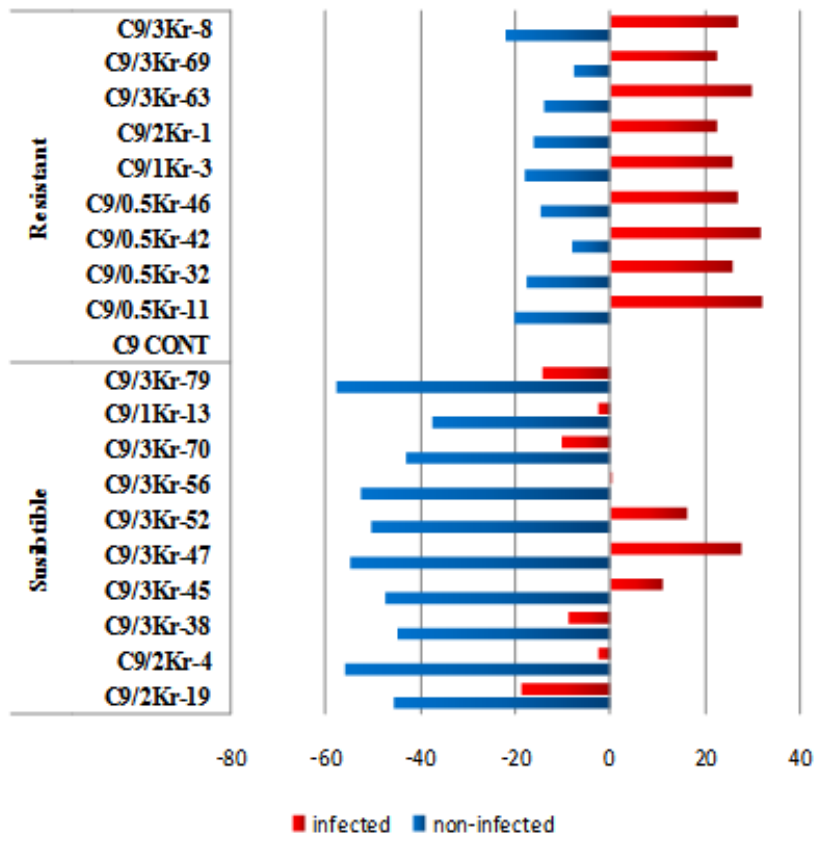

Figure 2 Percentage of Increase/Decrease over control (\%IDOC) of Phenylalanine ammonia layase (PAL) in healthy and Ustilago scitaminea infected sugarcane.

\section{Analysis of Esterase (EST)}

The levels of esterases were significantly increased in the (RI) and (RNI) clones compared to the infected and non-infected control, respectively, as well as the (SI) and (SNI) control. The percentage of IDOC in the resistant non-infected clones ranged from $1.69 \%$ to $41.13 \%$ compared to the non-infected control while in the (RI) clones, the increase ranged from $5.99 \%$ to $23.62 \%$ compared to (RNI) control. In infected susceptible clones the enzyme level decreased significantly compared to the infected control, the reduction ranged from $2.58 \%$ to $20.47 \%$ (Table 3 ).

Kim et al., ${ }^{42}$ reported that esterase of Capsicum annum inhibit the appressorium formation of Glomerella cingulata. Zhang et al., ${ }^{43}$ reported a detoxification gene for Albicidin from Pantoea dispersa. The gene encodes an esterase and it abolishes the capacity of Xanthomonas albilineans to release albicidin toxin and incite the symptoms of leaf scald disease in sugarcane. Koretsky ${ }^{44}$ suggested the role of esterases in the development of resistance to fusarium infection in soy bean (Figure 3).

\section{Analysis of Peroxidase (POX)}

Data presented in Table 4 show that the enzyme levels significantly 
increased in the (RI) and (RNI) control compared to the (SI) and (SNI) clones. In the resistant non-infected control the enzyme level increased $29.96 \%$ to $66.07 \%$ over the non-infected control. On the other hand the increase of enzyme levels in the (RI) clones ranged from $5.20 \%$ to $27.02 \%$ over the (RI) control. The enzyme level in the
(SI) clones almost decreased 2 folds compared to the infected control. The range of enzyme reduction ranged from $29.73 \%$ to $46.43 \%$ ). The obtained data suggest the presence of an association between resistance and the increase of peroxidase level in the plant (Figure 4).

Table 2 Specific activity of phenyl alanine ammonia layase (PAL) in healthy and Ustilago scitaminea infected sugarcane resistant and susceptible mutants

\begin{tabular}{|c|c|c|c|c|c|c|}
\hline \multirow{2}{*}{ Resistance } & \multirow{2}{*}{ Clone } & \multicolumn{4}{|c|}{ PAL (moles of transcinnamic acid/h $\mathbf{h}^{-1} \mathrm{~g}^{-1}$ fresh $\mathrm{wt}$ ) } & \multirow{2}{*}{ Mean } \\
\hline & & Non-Infected & $\%$ IDOC & Infected & $\%$ IDOC & \\
\hline \multirow{10}{*}{ Susceptible } & C9/2Kr-19 & $0.0084 \mathrm{Imn}$ & $\downarrow 45.67$ & $0.0163 \mathrm{gh}$ & $\downarrow 18.73$ & \multirow{10}{*}{$0.0140 \mathrm{~B}$} \\
\hline & $\mathrm{C} 9 / 2 \mathrm{Kr}-4$ & $0.0068 \mathrm{mn}$ & $\downarrow 55.84$ & $0.0196 \mathrm{de}$ & $\downarrow 2.48$ & \\
\hline & C9/3Kr-38 & $0.0085 \mathrm{Im}$ & $\downarrow 44.80$ & $0.0183 \mathrm{def}$ & $\downarrow 8.78$ & \\
\hline & C9/3Kr-45 & $0.008 \mathrm{IImn}$ & $\downarrow 47.61$ & $0.0223 c$ & $\uparrow I I . I I$ & \\
\hline & C9/3Kr-47 & $0.00691 \mathrm{mn}$ & $\downarrow 54.97$ & $0.0257 a$ & $\uparrow 27.69$ & \\
\hline & C9/3Kr-52 & $0.0076 \mathrm{lmn}$ & $\downarrow 50.43$ & $0.0233 \mathrm{bc}$ & $\uparrow 16.08$ & \\
\hline & C9/3Kr-56 & $0.0073 \mathrm{lmn}$ & $\downarrow 52.59$ & $0.0201 d$ & $\uparrow 0.16$ & \\
\hline & C9/3Kr-70 & $0.0088 I$ & $\downarrow 43.07$ & $0.0180 \mathrm{efg}$ & $\downarrow 10.28$ & \\
\hline & C9/IKr-13 & $0.0096 \mathrm{n}$ & $\downarrow 37.66$ & $0.0196 \mathrm{fgh}$ & $\downarrow 2.48$ & \\
\hline & C9/3Kr-79 & $0.0065 n$ & $\downarrow 57.79$ & $0.0172 \mathrm{fgh}$ & $\downarrow 14.42$ & \\
\hline \multirow{12}{*}{ Resistant } & Mean & 0.0078 & & 0.0201 & & \multirow{12}{*}{$0.0191 \mathrm{~A}$} \\
\hline & C9 Cont & $0.0154 \mathrm{hi}$ & - & $0.0201 d$ & - & \\
\hline & C9/0.5Kr-II & $0.0123 \mathrm{jk}$ & $\downarrow 20.12$ & $0.0265 a$ & $\uparrow 32.00$ & \\
\hline & $\mathrm{C} 9 / 0.5 \mathrm{Kr}-32$ & $0.0127 \mathrm{jk}$ & $\downarrow 17.74$ & $0.0253 a$ & $\uparrow 25.87$ & \\
\hline & $\mathrm{C} 9 / 0.5 \mathrm{Kr}-42$ & $0.014 \mathrm{lij}$ & $\downarrow 8.22$ & $0.0265 a$ & $\uparrow 31.84$ & \\
\hline & $\mathrm{C} 9 / 0.5 \mathrm{Kr}-46$ & $0.0131 \mathrm{jk}$ & $\downarrow|4.7|$ & $0.0255 a$ & $\uparrow 27.03$ & \\
\hline & C9/IKr-3 & $0.0126 \mathrm{jk}$ & $\downarrow 18.18$ & $0.0253 a$ & $\uparrow 25.70$ & \\
\hline & C9/2Kr-I & $0.0129 \mathrm{jk}$ & $\downarrow 16.01$ & $0.0246 a b$ & $\uparrow 22.55$ & \\
\hline & $\mathrm{C} 9 / 3 \mathrm{Kr}-63$ & $0.0133 \mathrm{jk}$ & $\downarrow 13.85$ & $0.026 \mathrm{la}$ & $\uparrow 30.01$ & \\
\hline & C9/3Kr-69 & $0.0142 \mathrm{ij}$ & $\downarrow 7.57$ & $0.0246 a b$ & $\uparrow 22.55$ & \\
\hline & $\mathrm{C} / 3 \mathrm{Kr}-8$ & $0.0120 \mathrm{k}$ & $\downarrow 22.07$ & $0.0255 \mathrm{a}$ & $\uparrow 27.03$ & \\
\hline & Mean & 0.0133 & & 0.0250 & & \\
\hline \multicolumn{2}{|l|}{ Mean } & $0.0118 \mathrm{~B}$ & & $0.0232 \mathrm{~A}$ & & \\
\hline \multicolumn{7}{|c|}{ LSD at $(0.05)$ for: } \\
\hline \multicolumn{2}{|c|}{ Resistance (R): } & \multicolumn{4}{|l|}{0.00232} & \\
\hline \multicolumn{2}{|l|}{ Infection (I): } & \multicolumn{4}{|l|}{0.00562} & \\
\hline \multicolumn{2}{|l|}{ Clones (C): } & \multicolumn{4}{|l|}{0.00232} & \\
\hline \multicolumn{2}{|l|}{ RxIxC: } & \multicolumn{4}{|l|}{0.001709} & \\
\hline
\end{tabular}

*IDOC, \% of Increase/Decrease over control; up arrows ( $\uparrow$ ), increase; down arrow $(\downarrow)$, decrease

*Different letters in means indicate a significant difference

In plants, the increased production of both the superoxide radical and $\mathrm{H}_{2} \mathrm{O}_{2}$ is a common feature of defence response to challenge by the microbial pathogen and elicitors. ${ }^{45}$ It has been proposed that, the rapid increase in either intra or extra cellular $\mathrm{H}_{2} \mathrm{O}_{2}$ is involved in the induction of execution of the hypersensitive response. ${ }^{46}$ Bestwick et al., ${ }^{47}$ reported that, Cytochrome c peroxidase is a key enzyme during the synthesis of phytoalexin which has some inhibitory effect on disease.

Plant peroxidases can be directly involved in defence mechanisms acting as a catalyst for the polymerization of phenolic compounds to form lignin and suberin in the cell wall, which can act as mechanical barriers to block the spread of the pathogen in the plant. ${ }^{48}$ The importance of peroxidases during plant resistance against pathogens has been demonstrated for the interaction between rice and Xanthomonas oryzae pv. oryzae ${ }^{49}$ and between cotton and X. campestris pv. Malvacerum. ${ }^{50}$

Another important difference was the enhancement in the resistant cultivar of peroxidase, an enzyme that uses free phenolics as substrates for the activation of the important mechanisms of resistance of sugar cane leaves to the fungal pathogen. ${ }^{51}$

Turk $^{52}$ and Que et al., ${ }^{53}$ reported that cytochrome c peroxidase is newly induced after infection, and the author believed that hydrogen peroxide redox type cytochrome c reaction (2 cytochrome c $(\mathrm{Fe} 2+)+\mathrm{H}_{2} \mathrm{O}_{2}+2 \mathrm{H}+\rightarrow 2$ cytochrome c $\left.\left(\mathrm{Fe}^{3+}\right)+2 \mathrm{H}_{2} \mathrm{O}\right)$ was catalyzed by the up-regulated expression of cytochrome $\mathrm{c}$ peroxidase, which 
improved the increasing synthesis of phytoalexin and inhibited the growth of S. scitamineum and thus reduced the harm of S. scitamineum.

\section{\% IDOC of Esterase (EST)}

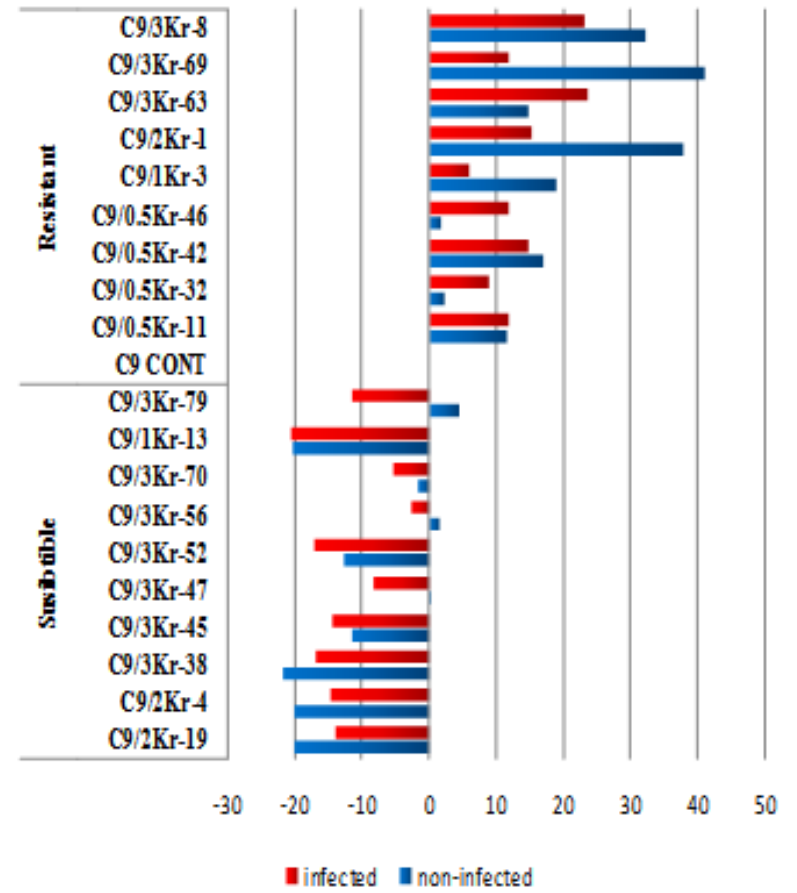

Figure 3 Percentage of Increase/Decrease over control (\%IDOC) of Esterase (EST) in healthy and Ustilago scitaminea infected sugarcane resistant and susceptible GT54-9 mutants.

\section{$\%$ IDOC of Peroxidase (POX)}

\begin{tabular}{|c|c|}
\hline \multirow{10}{*}{ 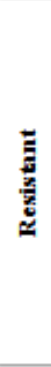 } & $\mathrm{C} 9 / 3 \mathrm{Kr}-8$ \\
\hline & $\mathrm{C} 9 / 3 \mathrm{Kr}-69$ \\
\hline & $\mathrm{C} 9 / 3 \mathrm{Kr}-63$ \\
\hline & $\mathrm{C} 9 / 2 \mathrm{Kr}-\mathrm{l}$ \\
\hline & $\mathrm{C} 9 / 1 \mathrm{Kr}-3$ \\
\hline & C $9 / 0.5 \mathrm{Kr}-46$ \\
\hline & $\mathrm{C} 9 / 0.5 \mathrm{Kr}-42$ \\
\hline & $\mathrm{C} 9 / 0.5 \mathrm{Kr}-32$ \\
\hline & C $9 / 0.5 \mathrm{Kr}-11$ \\
\hline & $\mathrm{C} 9 \mathrm{CONT}$ \\
\hline \multirow{10}{*}{ 总 } & C $9 / 3 \mathrm{Kr}-79$ \\
\hline & $\mathrm{C} 9 / \mathrm{lKr}-13$ \\
\hline & $\mathrm{C} 9 / 3 \mathrm{Kr}-70$ \\
\hline & $\mathrm{C} 9 / 3 \mathrm{Kr}-56$ \\
\hline & C $9 / 3 \mathrm{Kr}-52$ \\
\hline & $\mathrm{C} 9 / 3 \mathrm{Kr}-47$ \\
\hline & $\mathrm{C} 9 / 3 \mathrm{Kr}-45$ \\
\hline & C $9 / 3 \mathrm{Kr}-38$ \\
\hline & $\mathrm{C} 9 / 2 \mathrm{Kr}-4$ \\
\hline & C $9 / 2 \mathrm{Kr}-19$ \\
\hline
\end{tabular}

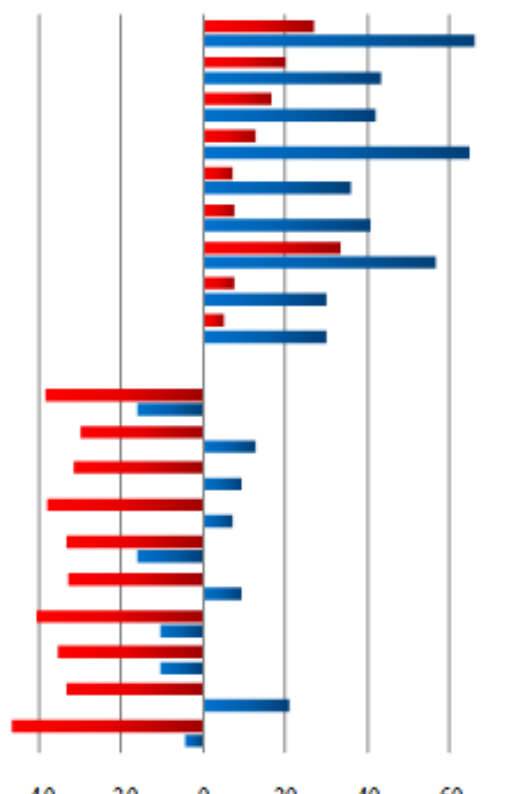

$-60$

infected non-infected

Figure 4 Percentage of Increase/Decrease over control (\%IDOC) of Peroxidase (POX) in healthy and $U$. scitaminea infected sugarcane resistant and susceptible GT54-9 mutants.

\section{Analysis of chitinase}

Data presented in Table 5 show that all the (SI) and (SNI) clones have a low level of chitinase compared to the infected and non infected control. The decrease percentage of chitinase over control IDOC in the susceptible clones ranged from $40.17 \%$ to $51.84 \%$, while in the infected clones the decrease over control ranged from $52.89 \%$ to $67.67 \%$ (Figure 5).

In resistant non infected clones the level of chitinase significantly increased in some of the tested clones while it was nonsignificant with the others compared to the non infected control $(1.181 \%$ to $20.997 \%)$. In (RI) clones the level of chitinase increased over control in some clones and decreased in the others.

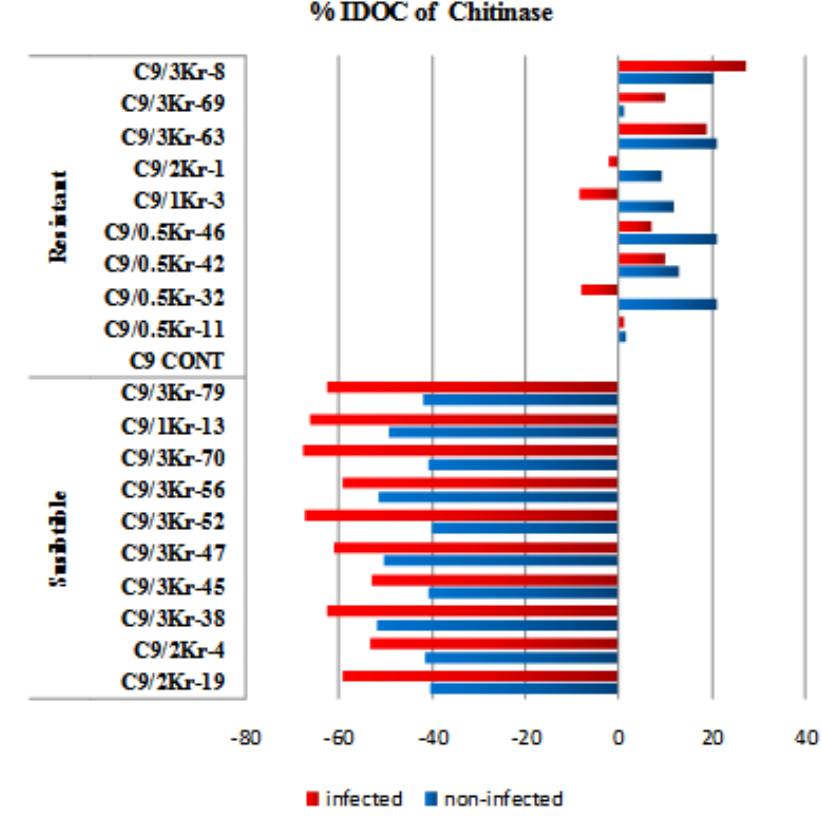

Figure 5 Percentage of Increase/Decrease over control (\%IDOC) of Chitinase in healthy and $U$. scitaminea infected sugarcane resistant and susceptible GT549 mutants.

\section{Analysis of $\beta-1,3$ glucanase}

The results of the present study demonstrated that, the specific activity of $\beta-1,3$ glucanase showed similar pattern of decrease as for the activity of chitinase in the (SI) and (SNI) clones compared to the infected and non infected control (Table 6). In contrast to chitinase pattern of activity of the (RI) and (RNI) clones the specific activity of $\beta-1,3$ glucanase in all the tested colones decreased compared to the non infected control while in the infected clones some of the tested clones showed a reduction in the specific activity and the others showed increases (Figure 6).

$\mathrm{Kuc}^{54}$ reveled that, the plant response phase against the infection includes the accumulation of different compounds such as phytoalexins (i.e. low molecular mass antimicrobial compounds that accumulate at sites of infection), systemic enzymes that degrade pathogens (e.g. chitinases, $\beta-1,3-$ glucanases and proteases). Wu et al., ${ }^{55}$ reported, two defense related genes encoding the anionic peroxidase and acidic chitinase were induced in transgenic Solanum tuberosum by the action of a broad range of fungal pathogens.

Mauch et al., ${ }^{56}$ reported that, Chitinase and glucanase are the most 
widely used approach of developing fungus resistant plants they found that, both enzymes showed over-expression in transgenic plants. They stated that, chitin and glucan comprise major components of the cell wall of most of the fungi. Over-expression of these hydrolytic enzymes in the plant cells is postulated to cause hyphal lysis, thereby inhibiting fungal growth. Broque et al., ${ }^{57}$ constitutively expressed bean chitinase in tobacco and Brassica napus to enhance resistance towards Rhizoctonia solani. Among the PR proteins hydrolytic enzymes (chitinase and glucanase), Osmotins, Thionins and Defensins are specially important.

Table 3 Specific activity of Esterase (EST) in healthy and U. scitaminea infected sugarcane resistant and susceptible mutants

\begin{tabular}{|c|c|c|c|c|c|c|}
\hline \multirow{2}{*}{ Resistance } & \multirow{2}{*}{ Clone } & \multicolumn{4}{|c|}{ Esterase healthy (units $\mathrm{min}^{-1} \mathrm{~g}^{-1}$ fresh wt) } & \multirow{2}{*}{ Mean } \\
\hline & & Non- Infected & $\%$ IDOC & Infected & $\%$ IDOC & \\
\hline \multirow{10}{*}{ Susceptible } & C9/2Kr- 19 & 0.1868[ & $\downarrow 20.05$ & $0.2988 \mathrm{~m}$ & $\downarrow 13.96$ & \multirow{10}{*}{$0.2568 \mathrm{~B}$} \\
\hline & $\mathrm{C} 9 / 2 \mathrm{Kr}-4$ & 0.1865[ & $\downarrow 20.19$ & $0.2963 n$ & $\downarrow \mid 4.67$ & \\
\hline & C9/3Kr-38 & $0.1827 /$ & $\downarrow 21.83$ & $0.2885 \circ$ & $\downarrow 16.92$ & \\
\hline & C9/3Kr-45 & $0.2070 y$ & $\downarrow 11.42$ & $0.2970 n$ & $\downarrow \mid 4.48$ & \\
\hline & C9/3Kr-47 & $0.2342 w$ & $\uparrow 0.19$ & $0.3184 k$ & $\downarrow 8.32$ & \\
\hline & C9/3Kr-52 & $0.2037 z$ & $\downarrow 12.85$ & 0.28730 & $\downarrow 17.26$ & \\
\hline & $\mathrm{C} 9 / 3 \mathrm{Kr}-56$ & $0.2370 v$ & $\uparrow I .4 I$ & $0.3383 \mathrm{~h}$ & $\downarrow 2.58$ & \\
\hline & C9/3Kr-70 & $0.2298 x$ & $\downarrow 1.65$ & $0.3284 i$ & $\downarrow 5.44$ & \\
\hline & C9/IKr-I3 & 0.1864[ & $\downarrow 20.23$ & $0.2772 p$ & $\downarrow 20.47$ & \\
\hline & C9/3Kr-79 & $0.2442 t$ & $\uparrow 4.47$ & $0.3077 \mid$ & $\downarrow|I .4|$ & \\
\hline \multirow{12}{*}{ Resistant } & Mean & 0.2098 & & 0.3037 & & \multirow{18}{*}{$0.3333 \mathrm{~A}$} \\
\hline & C9 Cont & $0.2337 w$ & & $0.3473 \mathrm{~g}$ & & \\
\hline & C9/0.5Kr-I I & $0.2607 \mathrm{~s}$ & $\uparrow 11.53$ & $0.3883 \mathrm{~d}$ & $\uparrow 11.79$ & \\
\hline & $\mathrm{C} / 0.5 \mathrm{Kr}-32$ & $0.2392 u$ & $\uparrow 2.33$ & $0.3783 \mathrm{e}$ & $\uparrow 8.93$ & \\
\hline & $\mathrm{C} 9 / 0.5 \mathrm{Kr}-42$ & $0.2735 q$ & $\uparrow 17.03$ & $0.398 \mathrm{Ic}$ & $\uparrow 14.63$ & \\
\hline & $\mathrm{C} 9 / 0.5 \mathrm{Kr}-46$ & $0.2377 u v$ & $\uparrow 1.69$ & $0.3880 \mathrm{~d}$ & $\uparrow \mid I .7 I$ & \\
\hline & C9/IKr-3 & $0.2777 p$ & $\uparrow 18.8 \mathrm{I}$ & $0.368 \mathrm{If}$ & $\uparrow 5.99$ & \\
\hline & $\mathrm{C} 9 / 2 \mathrm{Kr}-\mathrm{I}$ & $0.3222 j$ & $\uparrow 37.85$ & $0.4007 b$ & $\uparrow 15.36$ & \\
\hline & C9/3Kr-63 & $0.2680 r$ & $\uparrow 14.67$ & $0.4293 a$ & $\uparrow 23.62$ & \\
\hline & C9/3Kr-69 & $0.3298 \mathrm{i}$ & $\uparrow 4 I .13$ & $0.3879 d$ & $\uparrow 11.69$ & \\
\hline & $\mathrm{C} 9 / 3 \mathrm{Kr}-8$ & $0.3090 \mathrm{I}$ & $\uparrow 32.22$ & $0.4279 a$ & $\uparrow 23.19$ & \\
\hline & Mean & 0.275 I B & & $0.3914 \mathrm{~A}$ & & \\
\hline Mean & & 0.2587 & & 0.3664 & & \\
\hline \multicolumn{6}{|c|}{ LSD at $(0.05)$ for: } & \\
\hline \multicolumn{2}{|c|}{ Resistance (R): } & \multicolumn{4}{|l|}{0.0023} & \\
\hline \multicolumn{2}{|l|}{ Infection (I): } & \multicolumn{4}{|l|}{0.0036} & \\
\hline \multicolumn{2}{|l|}{ Clones (C): } & \multicolumn{4}{|l|}{0.0023} & \\
\hline \multicolumn{2}{|l|}{ RxIxC: } & \multicolumn{4}{|l|}{0.0017} & \\
\hline
\end{tabular}

*IDOC, \% of Increase/Decrease over control; up arrows ( $\uparrow$ ), increase; down arrow $(\downarrow)$, decrease

*Different letters in means indicate a significant difference

EST: Esterase

Table 4 Specific activity of Peroxidase (POX) in healthy and U. scitaminea infected sugarcane resistant and susceptible mutants

\begin{tabular}{|c|c|c|c|c|c|c|}
\hline \multirow{2}{*}{ Resistance } & \multirow{2}{*}{ Clone } & \multicolumn{4}{|c|}{ Peroxidase (units $\min ^{-1} \mathrm{~g}^{-1}$ fresh $w t$ ) } & \multirow{2}{*}{ Mean } \\
\hline & & Non- Infected & \% IDOC & Infected & \% IDOC & \\
\hline \multirow{11}{*}{ Susceptible } & C9/2Kr-I9 & $0.0163 \mathrm{t}$ & $\downarrow 4.483$ & $0.0283 q$ & $\downarrow 46.433$ & \multirow{11}{*}{$0.0255 \mathrm{~B}$} \\
\hline & $\mathrm{C} 9 / 2 \mathrm{Kr}-4$ & $0.0207 r$ & $\uparrow 20.857$ & $0.0353 \mathrm{mn}$ & $\downarrow 33.207$ & \\
\hline & $\mathrm{C} 9 / 3 \mathrm{Kr}-38$ & I. tu & $\downarrow|0.33|$ & 0.0341 no & $\downarrow 35.448$ & \\
\hline & C9/3Kr-45 & $0.0153 \mathrm{tu}$ & $\downarrow|0.33|$ & $0.0313 p$ & $\downarrow 40.719$ & \\
\hline & C9/3Kr-47 & $0.0187 \mathrm{~s}$ & $\uparrow 9.1618$ & $0.0356 \mathrm{mn}$ & $\downarrow 32.638$ & \\
\hline & C9/3Kr-52 & $0.0143 \mathrm{u}$ & $\downarrow 16.179$ & $0.0352 \mathrm{mn}$ & $\downarrow 33.428$ & \\
\hline & C9/3Kr-56 & $0.0183 \mathrm{~s}$ & $\uparrow 7.2125$ & 0.0328 op & $\downarrow 37.94 \mid$ & \\
\hline & C9/I3Kr-70 & $0.0187 \mathrm{~s}$ & $\uparrow 9.1618$ & $0.0362 \mathrm{~lm}$ & $\downarrow 31.47 \mid$ & \\
\hline & $\mathrm{C} 9 / \mathrm{Kr}-3$ & $0.0193 \mathrm{u}$ & $\uparrow 12.865$ & $0.037 \mathrm{I}$ op & $\downarrow 29.734$ & \\
\hline & C9/3Kr-79 & $0.0143 \mathrm{u}$ & $\downarrow 16.179$ & 0.0326 op & $\downarrow 38.257$ & \\
\hline & Mean & 0.0171 & & 0.0338 & & \\
\hline
\end{tabular}




\begin{tabular}{|c|c|c|c|c|c|c|}
\hline \multirow{2}{*}{ Resistance } & \multirow{2}{*}{ Clone } & \multicolumn{4}{|c|}{ Peroxidase (units $\min ^{-1} \mathrm{~g}^{-1}$ fresh $\mathrm{wt}$ ) } & \multirow{2}{*}{ Mean } \\
\hline & & Non- Infected & $\%$ IDOC & Infected & $\%$ IDOC & \\
\hline \multirow{11}{*}{ Resistant } & C9 Cont & $0.0277 \mathrm{q}$ & & $0.0528 \mathrm{~g}$ & & \multirow{17}{*}{$0.0495 \mathrm{~A}$} \\
\hline & C9/0.5Kr-I I & $0.03601 \mathrm{mn}$ & $\uparrow 29.963$ & $0.0556 \mathrm{f}$ & $\uparrow 5.2083$ & \\
\hline & C9/0.5Kr-32 & $0.03601 \mathrm{mn}$ & $\uparrow 29.963$ & $0.0567 \mathrm{f}$ & $\uparrow 7.3864$ & \\
\hline & $\mathrm{C} 9 / 0.5 \mathrm{Kr}-42$ & $0.0433 \mathrm{i}$ & $\uparrow 56.438$ & $0.0703 \mathrm{a}$ & $\uparrow 33.207$ & \\
\hline & C9/0.5Kr-46 & $0.0390 \mathrm{jk}$ & $\uparrow 40.794$ & $0.0568 \mathrm{f}$ & $\uparrow 7.5442$ & \\
\hline & C9/IKr-3 & $0.0377 \mathrm{kl}$ & $\uparrow 35.980$ & $0.0566 \mathrm{f}$ & $\uparrow 7.260 \mathrm{I}$ & \\
\hline & C9/2Kr-I & $0.0457 \mathrm{~h}$ & $\uparrow 64.86 \mathrm{I}$ & $0.0596 \mathrm{e}$ & $\uparrow \mid 2.878$ & \\
\hline & C9/3Kr-63 & $0.0393 \mathrm{jk}$ & $\uparrow 41.997$ & $0.0616 \mathrm{~d}$ & $\uparrow 16.635$ & \\
\hline & C9/3Kr-69 & $0.0397 \mathrm{j}$ & $\uparrow 43.201$ & $0.0634 c$ & $\uparrow 20.138$ & \\
\hline & C9/3Kr-8 & $0.0460 \mathrm{~h}$ & $\uparrow 66.065$ & $0.067 \mathrm{I} \mathrm{b}$ & $\uparrow 27.020$ & \\
\hline & Mean & 0.0390 & & 0.0601 & & \\
\hline \multicolumn{2}{|c|}{ Mean } & $0.0328 \mathrm{~B}$ & & $0.0529 A$ & & \\
\hline \multicolumn{6}{|c|}{ LSD at $(0.05)$ for: } & \\
\hline \multicolumn{2}{|c|}{ Resistance (R): } & 0.00232 & & & & \\
\hline \multicolumn{2}{|c|}{ Infection (I): } & 0.00613 & & & & \\
\hline \multicolumn{2}{|c|}{ Clones (C): } & 0.00232 & & & & \\
\hline \multicolumn{2}{|l|}{ RxIxC: } & 0.0017 & & & & \\
\hline
\end{tabular}

*IDOC, \% of Increase/Decrease over control; up arrows ( $\uparrow$ ), increase; down arrow $(\downarrow)$, decrease

*Different letters in means indicate a significant difference

POX: Peroxidase

Table 5 Specific activity of Chitinase in healthy and U. scitaminea infected sugarcane resistant and susceptible mutants

\begin{tabular}{|c|c|c|c|c|c|c|}
\hline \multirow{2}{*}{ Resistance } & \multirow{2}{*}{ Clone } & \multicolumn{4}{|c|}{ Chitinase (units $\mathrm{min}^{-1} \mathrm{~g}^{-1}$ fresh wt) } & \multirow[t]{2}{*}{ Mean } \\
\hline & & Non-Infected & $\%$ IDOC & Infected & $\%$ IDOC & \\
\hline \multirow{10}{*}{ Susceptible } & C9/2Kr-I9 & $5.1288 \circ$ & $\downarrow 40.3043$ & I3.7268i & $\downarrow 59.3330$ & \multirow{10}{*}{$8.9131 \mathrm{~B}$} \\
\hline & $\mathrm{C} 9 / 2 \mathrm{Kr}-4$ & $5.0156 \circ$ & $\downarrow 41.6216$ & I5.7488h & $\downarrow 53.3428$ & \\
\hline & C9/3Kr-38 & $4.1374 p$ & $\downarrow 51.8439$ & $12.6970 \mathrm{j}$ & $\downarrow 62.384 \mathrm{I}$ & \\
\hline & $\mathrm{C} 9 / 3 \mathrm{Kr}-45$ & $5.0831 \circ$ & $\downarrow 40.8367$ & $\mathrm{I} 5.90 \mathrm{IIh}$ & $\downarrow 52.8917$ & \\
\hline & $\mathrm{C} 9 / 3 \mathrm{Kr}-47$ & $4.2670 \mathrm{p}$ & $\downarrow 50.3352$ & $13.1216 \mathrm{j}$ & $\downarrow 61.1261$ & \\
\hline & C9/3Kr-52 & $5.1407 \circ$ & $\downarrow 40.1660$ & $1 \mathrm{I} .0142 \mathrm{k}$ & $\downarrow 67.3694$ & \\
\hline & $\mathrm{C} 9 / 3 \mathrm{Kr}-56$ & $4.1642 \mathrm{p}$ & $\downarrow 51.5317$ & I3.7392i & $\downarrow 59.2966$ & \\
\hline & C9/3Kr-70 & $5.0872 \circ$ & $\downarrow 40.7887$ & $10.9125 \mathrm{k}$ & $\downarrow 67.6708$ & \\
\hline & C9/IKr-I 3 & $4.3564 \circ$ & $\downarrow 49.2947$ & I I.3433j & $\downarrow 66.3945$ & \\
\hline & C9/3Kr-79 & $4.9858 \circ$ & $\downarrow 41.9693$ & $12.6920 \mathrm{j}$ & $\downarrow 62.3989$ & \\
\hline \multirow{12}{*}{ Resistant } & Mean & 4.7366 & & I3.0897 & & \multirow{18}{*}{$22.6195 \mathrm{~A}$} \\
\hline & C9 Cont & $8.5916 \mathrm{n}$ & & $33.7543 e$ & & \\
\hline & C9/0.5Kr-I I & $8.7170 n$ & $\uparrow 1.4599$ & $34.1254 \mathrm{e}$ & $\uparrow 1.0994$ & \\
\hline & $\mathrm{C} 9 / 0.5 \mathrm{Kr}-32$ & $10.4055 \mid$ & $\uparrow 21.1131$ & $31.0864 \mathrm{~g}$ & $\downarrow 7.9037$ & \\
\hline & $\mathrm{C} / 0.5 \mathrm{Kr}-42$ & $9.7082 \mathrm{~m}$ & $\uparrow 12.9969$ & $37.0859 c$ & $\uparrow 9.8703$ & \\
\hline & $\mathrm{C} 9 / 0.5 \mathrm{Kr}-46$ & $10.3956 \mid$ & $\uparrow 20.997 \mathrm{I}$ & $36.1056 d$ & $\downarrow 6.9660$ & \\
\hline & C9/IKr-3 & $9.6148 \mathrm{~m}$ & $\uparrow 11.9091$ & $30.8785 g$ & $\downarrow 8.5197$ & \\
\hline & $\mathrm{C} 9 / 2 \mathrm{Kr}-\mathrm{I}$ & $9.3880 \mathrm{~m}$ & $\uparrow 9.2698$ & $32.9592 f$ & $\downarrow 2.3556$ & \\
\hline & $\mathrm{C} 9 / 3 \mathrm{Kr}-63$ & $|0.3986|$ & $\uparrow 21.0317$ & $40.0965 b$ & $\uparrow 18.789$ & \\
\hline & C9/3Kr-69 & $8.6931 \mathrm{n}$ & $\uparrow 1.1810$ & $37.1152 c$ & $\uparrow 9.9569$ & \\
\hline & C9/3Kr-8 & $10.3336 \mid$ & $\uparrow 20.2759$ & $42.9358 a$ & $\uparrow 27.200$ & \\
\hline & Mean & 9.6246 & & $35.6 \mid 43$ & & \\
\hline Mean & & 8.2437 B & & 28.8700 A & & \\
\hline \multicolumn{6}{|c|}{ LSD at $(0.05)$ for: } & \\
\hline \multicolumn{2}{|c|}{ Resistance (R): } & \multicolumn{4}{|l|}{0.684} & \\
\hline \multicolumn{2}{|l|}{ Infection (I): } & \multicolumn{4}{|l|}{0.669} & \\
\hline \multicolumn{2}{|l|}{ Clones (C ): } & \multicolumn{4}{|l|}{0.684} & \\
\hline \multicolumn{2}{|l|}{ RxlxC: } & \multicolumn{4}{|l|}{0.504} & \\
\hline
\end{tabular}

*IDOC, \% of Increase/Decrease over control; up arrows $(\uparrow)$, increase; down arrow $(\downarrow)$, decrease

*Different letters in means indicate a significant difference

Citation: Esh AMH, Guirgis AA, El-kholi MMA, et al.The activity of pathogenesis related proteins in smut resistant and susceptible sugarcane (GT54-9) mutants induced by gamma radiation. Adv Plants Agric Res. 20 I4; I (4): I 46- I 56. DOI: I0. I5406/apar.20 I4.0 I.00024 
Table 6 Specific activity of $\beta-I, 3$ glucanase in healthy and U. scitaminea infected sugarcane resistant and susceptible mutants

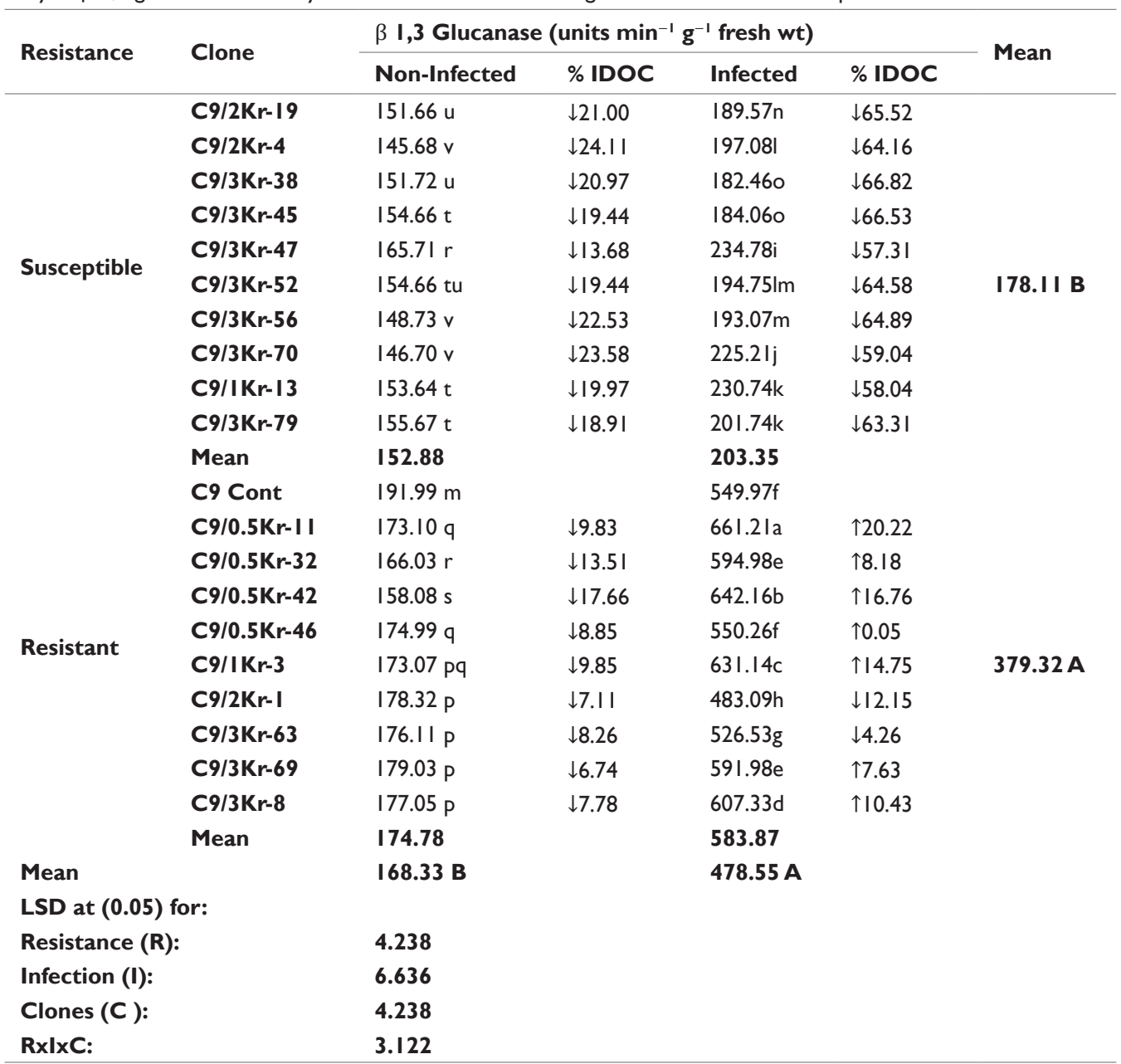

*IDOC, \% of Increase/Decrease over control; up arrows ( $\uparrow$ ), increase; down arrow $(\downarrow)$, decrease

*Different letters in means indicate a significant difference

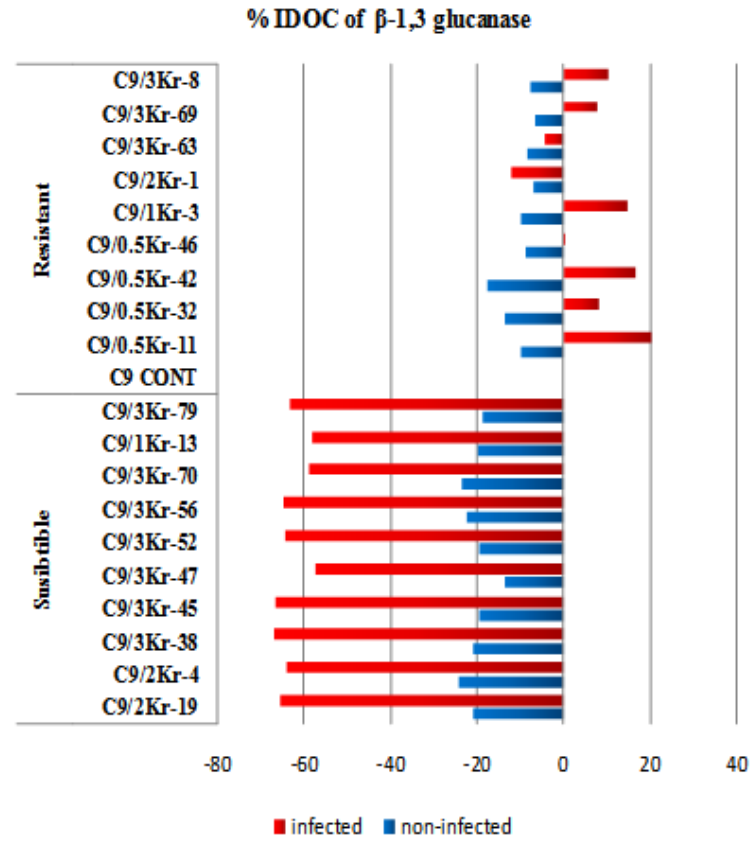

Figure 6 Percentage of Increase/Decrease over control (\%IDOC) of $\beta$ I,3 glucanase in healthy and U. scitaminea infected sugarcane resistant and susceptible GT54-9 mutants.

Citation: Esh AMH, Guirgis AA, El-kholi MMA, et al.The activity of pathogenesis related proteins in smut resistant and susceptible sugarcane (GT54-9) mutants induced by gamma radiation. Adv Plants Agric Res. 20 I4; I (4): I 46- I 56. DOI: I0.15406/apar.20 I4.01.00024 


\section{Acknowledgements}

None.

\section{Conflict of interest}

The author declares no conflict of interest.

\section{References}

1. Singh N, Somai BM, Pillay D. Smut disease assessment by PCR and microscopy in inoculated tissue cultured sugarcane cultivars. Plant Science. 2004;167(5):987-994.

2. Martinez M, MedinaI I, Naranjo S, et al. Changes of some chemica parameters, involved in sucrose recovery from sugarcane juices, related to the susceptibility or resistance of sugarcane plants to smut (Ustilago scitaminea). International Sugar Journal. 2000;102(1221):445-448.

3. Kosuge T. The role of phenolics in host response to infection. Annual Review of Phytopathology. 1969;7:195-222.

4. Darvill AG, Albersheim P. Phytoalexins and their elicitors, a defense against microbial infection in plants. Annual Review of Plant Physiology. 1984;35:243-275.

5. Broglie KR, Benhamou N, Chet I. The role of cell wall degrading enzymes in fungal disease resistance. In: Chet I editor. Biotechnology in Plant Disease Control. New York, USA: Wiley-Liss; 1993. p. 139-156.

6. Vance CP, Kirk TK, Sherwood RT. Lignification as a mechanism of disease resistance. Annual Review of Phytopathology. 1980;18:259-288.

7. Espelie KE, Francheschi VR, Kolattukudy PE. Immunocytochemical localization and time course of appearance of an anionic peroxidase associated with suberization inwound-healing potato tuber tissue. Plant Physiol. 1986;81(2):487-492.

8. Benhamou N, Mazau D, Grenier J, et al. Time-course study of the accumulation of hydroxyproline-rich glycoproteins in roots cells of susceptible and resistant plants infected by Fusarium oxysporum f.sp. radicis-lycopersici. Planta. 1991;184(2):196-208.

9. Van Loon LC, Gerritsen YAM. Localization of pathogenesis-related proteins in infected and non-infected leaves of Samsun NN tobacco during the hypersensitive reaction to tobacco mosaic virus. Plant Sci. 1989;63(2):131-140.

10. Van Loon LE, Van Strien EA. The families of pathogenesis related proteins, their activities, and comparative analysis of PR-1 type proteins. Physiol Mol Plant Pathol. 1999;55(2):85-97.

11. Datta K, Velazhahan R, Oliva N, et al. Over-expression of thaumatinlike protein $(\mathrm{PR}-5)$ gene in transgenic rice plants enhances environmentally friendly resistance to Rhizoctonia solani causing sheath blight disease. Theor Appl Genet. 1999;98(6-7):1138-1145.

12. Legaz ME, de Armas R, Pinon D, et al. Relationships between phenolics-conjugated polyamines and sensitivity of sugarcane to smut (Ustilago scitaminea). Journal of Experimental Botany. 1998;49(327):17231728 .

13. Pinon D, de Armas R, Vicente C, et al. Role of polyamines in the infection of sugarcane buds by Ustilago scitaminea spores. Plant Physiol Biochem. 1999;37(1):57-64.

14. Fontaniella B, Marquez A, Rodriguez CW, et al. A role for sugarcane glycoproteins in the resistance of sugarcane to Ustilago scitaminea. Plant Physiology and Biochemistry. 2002;40(10):881-889.

15. Millanes AM, Fontaniella B, Legaz ME, et al. Glycoproteins from sugarcane plants regulate cell polarity of Ustilago scitaminea teliospores. J Plant Physiol. 2005;62(3):253-265.
16. Legaz ME, Armas R de, Millanes AM, et al. Heterofructans and heterofructan containing glycoproteins from sugarcane:structure and function. Research and Development Biochemistry. 2005;6:31-51.

17. Gillaspie AG, Mock RG, Dean JL. Differentiation of Ustilago scitamenea isolates in greenhouse tests. Plant disease. 183;67(4):373-375.

18. Trione EJ. Growth and sporulation of Ustilago scitaminea,in vivoand in vitro. Mycological Research. 1990;94(4):489-493.

19. Bradford MM. A rapid and sensitive method for the quantitation of microgram quantities of protein utilizing the principle of protein-dye binding. Anal Biochem. 1976;72:248-254.

20. Malik CP, Singh MB. Extraction and estimation of amino acids and kito acids. In: Plant Enzymology and histo-Enzymology. India: New DelhiLud Hana; 1990.

21. Kar M, Mishra D. Catalase, peroxidase, and polyphenol oxidase activities during rice leaf senescence. Plant Physiol. 1976;57(2):315-319.

22. Zucker M. Sequential induction of phenylalanine ammonia-lyase and a lyase inactivating system in potato tuber disks. Plant Physiol. 1968;43(3):365-374.

23. Saunders JA, McClure JW. The suitability of a quantitative spectrophotometric assay for phenylalanine ammonia-lyase activity in barley, buckwheat and pea seedlings. Plant Physiol. 1974;54(3):412-413.

24. Van Asperen K. A study of housefly esterases by means of a sensitive colorimetric method. J Insect Physiol. 1962;8(4):401-416.

25. Reissig JL, Stringer JL, Leloir LF. A modified colorimetric method for the estimation of N-acetylamino sugars. J Biol Chem. 1995;217(2):959966

26. Singh RP, Singh US. Molecular methods in plant pathology. Lewis Press Inc, London, Tokyo: CRC Boca Raton; 1994. 58 p.

27. Naguib MI. Effect of seivn on the carbohydrate and nitrogen metabolism during the germination of cotton seeds. Ind J Agric Sci. 1964;35:179185

28. Naguib MI. Effect of maleic hydrazine on the nitrogen metabolism during the germination of cotton seeds. Ind J Exp Biol. 1965;2:149-152.

29. Snedecore GW, Cochran WG. Statistical methods. 7th ed. Iowa state University, USA: Pres Ames; 1982.

30. SPSS Inc. SPSS Base 8.0 for Windows User's Guide. Chicago, Illinois, USA: SPSS Inc; 1998.

31. Waller JM. Sugarcane smut (Ustilago scitaminea) in Kenya:Infection and resistance. Transactions of the British Mycological Society. 1970;54(3):405-414.

32. Alexander KC, Ramakrishnan K. Infection of the bud, establishment in the host and production of whips in sugarcane smut (Ustilago scitaminea) of sugarcane. Proceedings of the International Society of Sugarcane Technology. 1980;17:1452-1455.

33. Vaughan KC, Duke SO. Function of polyphenol oxidase in higher plants. Physiologia Plantarum. 1984;60(1):106-112.

34. Aniszewski T, Lieberei R, Gulewicz K. Research on catecholases, laccases and cresolases in plants. Recent progress and future needs. ACTA Biologica Cracoviensia Series Botanica. 2008;50(1):7-18.

35. Agrias GN. Plant Pathology. Indian reprints. India: Replika Press Pvt. Ltd; 1997;4(7):106-108.

36. Sundar AR, Viswanathan R, Malathi P, et al. Mechanism of resistance induced by plant activators against Colletotrichum falcatum in sugarcane. Archives of Phytopathology and Plant Protection. 2006;39(4):259272 
37. De Armas R, Santiago R, Legaz ME, et al. Levels of phenolic compounds and enzyme activity can be used to screen for resistance of sugarcane to smut (Ustilago scitaminea). Australasian Plant Pathology. 2007;36(1):32-38.

38. Singh J, Singh M, Chandra P, et al. Biochemical studies on resistance to red rot in sugarcane. Sugarcane. 1993;6:16-19.

39. Chylinska KM, Knypl JS. Decreased phenylalanine ammonia lyase and ribonuclease activity in side roots of carrot infested with northern rootknot nematode. Nematologica. 1975;21(2):129-133.

40. Ouyang YX, Kui LZ, Yun LC. Physiological and biochemical characterization of in vitro screened rice somaclonal variants resistant to Xanthomonas oryzae. Acta Phytopathologica Sinica. 2000;30(1):42-47.

41. Lian HG, Wu CG, Jie C, et al. The function of phenolic metabolism in resistant mechanism of gray leaf spot of corn. Acta Phytopathologica Sinica. 2005;33(4):342-346

42. Kim YS, Lee HH, Ko MK, et al. Inhibition of fungal appressorium formation by pepper (Capsicum annum) esterase. Mol Plant Microbe Interact. 2001;14(1):80-85.

43. Zhang LH, Birch RG. The gene for albicidin detoxification from Pantoea dispersa encodes an esterase which attenuates pathogenicity of Xanthomonas albilineas in sugarcane. Proc Natl Acad Sci USA. 1997;94(18):9984-9989.

44. Koretsky LS. The influence of Fusarium oxysporum infection and low temperatures on the activity of soybean esterase and PR proteins. Buvisindi. 2001;14:67-73.

45. Lamb C, Dixon RA. The oxidative burst in plant disease resistance Annu Rev Plant Physiol Plant Mol Biol. 1997;48:251-275.

46. Levine A, Tenhaken $\mathrm{R}$, Dixon $\mathrm{R}$, et al. $\mathrm{H}_{2 \mathrm{O} 2}$ from the oxidant burst or chestrates the plant hypersensitive disease resistance response. Cell. 1994;79(4):583-593.

47. Bestwick CS, Brown IR, Bennett MHR, et al. Localization of hydrogen peroxide accumulation during the hypersensitive reaction of lettuce cells to Pseudomonas syringae pv phaseolicola. Plant Cell. 1997;9(2):209 221.
48. Lebeda A, Luhova L, Sedlarova D, et al. The role of enzymes in plantfungal pathogens interactions. Journal of Plant Diseases Protection. 2001;108:89-111.

49. Chittor JM, Leac JE, White FF. Differential induction of a peroxidase gene family during infection of rice by Xanthomonas oryzae pv. oryzae. Mol Plant Microbe Interact. 1997;10(7):861-871.

50. Dai GH, Nicole M, Andary C, et al. Flavonoids accumulate in cell walls, middle lamellas and callose-rich papillae during an incompatible interaction between Xanthomonas campestris pv. malvacearum and cotton. Physiol Mol Plant Pathol. 1996;49(5):285-306.

51. Santiago RL, de Armas RM, Legaz E, et al. Separation from Ustilago scitaminea of different elicitors which modify the pattern of phenolic accumulation in sugarcane leaves. J Plant Pathol. 2008;90(1):87-96.

52. Turk FM. Phytoalexins:Defense or just a response to stress? J Cell Molecul Biol. 2002;1:1-6.

53. Que YX, Yang ZX, Xu LP, et al. Isolation and identification of differentially expressed genes in sugarcane infected by Ustilago scitaminea. Acta Agronomica Sinica. 2009;35(3):452-458.

54. Kuc J. Compounds from plants that regulate or participate in disease resistance. Ciba Found Symp. 1990;154:213-224

55. Wu G, Shortt BJ, Lawrence EB, et al. Activation of host defense mechanisms by elevated production of $\mathrm{H}_{2} \mathrm{O}_{2}$ in transgenic plants. Plant Physiol. 1997;115(2):427-435.

56. Mauch F, Staehelin LA. Functional implications of the subcellular localization of ethylene-induced chitinase and $\beta-1,3$-glucanase in bean leaves. Plant Cell. 1989;1(4):447- 457.

57. Broque K, Chet I, Holliday M, et al. Transgenic plants with enhanced resistance to the fungal pathogen Rhizoctonia solani. Science. 1991;254(5035):1194-1197. 